\title{
AN INDEX OF THE SEDIMENTATION RATE ON A MATHEMATICAL BASIS
}

\author{
L. J. CUTBILL
}

\section{From the Cheshire Joint Sanatorium}

MANY observers maintain that in the Westergren method of determining the sedimentation rate (S.R.) of red blood cells (R.B.Cs.) on a column of blood $200 \mathrm{~mm}$. high, the fall at the end of the first or second hour gives all the required information. In a method affected by many variable factors it is inadvisable to over-elaborate the technique; at the same time it is worth while to obtain the maximum of reliable information possible from the test. The first hour reading may give incomplete, and often misleading indication of the subsequent fall of the R.B.Cs. The second hour readings, though more constant than the first, may also fail to reveal subsequent variations in the S.R. It is useful and desirable where possible to record the fall of the R.B.Cs. over periods up to five hours when using the Westergren method.

In the following tables are given the sedimentation rates of bloods in which the first hour, second hour, or first two hours' readings are similar, but which show variations in subsequent observations. The figures represent millimetres per cent.

Table I.-First Hour Similar.

$\begin{array}{cccccc}\text { First } & \text { Second } & \text { Third } & \begin{array}{c}\text { Fourth } \\ \text { Hour. }\end{array} & \begin{array}{c}\text { Four. } \\ \text { Hourt }\end{array} & \text { Index. } \\ 1 & 3 & 4 & 6 & 8 & (36) \\ 1 & 16 & 23 & 26 & 28 & (160) \\ & & & & & \\ 5 & 9 & 12 & 16 & 20 & (104) \\ 5 & 33 & 39 & 42 & 44 & (282) \\ & & & & & \\ 15 & 27 & 33 & 35 & 36 & (256) \\ 15 & 34 & 41 & 47 & 50 & (324) \\ & & & & & \\ 25 & 36 & 42 & 45 & 48 & (344) \\ 25 & 43 & 52 & 58 & 60 & (416)\end{array}$




\begin{tabular}{|c|c|c|c|c|c|}
\hline $\begin{array}{l}\text { First } \\
\text { Hour. }\end{array}$ & $\begin{array}{c}\text { Second } \\
\text { Hour. }\end{array}$ & $\begin{array}{l}\text { Third } \\
\text { Hour. }\end{array}$ & $\begin{array}{c}\text { Fourth } \\
\text { Hour. }\end{array}$ & $\begin{array}{l}\text { Fifth } \\
\text { Hour. }\end{array}$ & Index. \\
\hline $\begin{array}{l}1 \\
1 \\
2\end{array}$ & $\begin{array}{l}4 \\
4 \\
4\end{array}$ & $\begin{array}{l}6 \\
8 \\
8\end{array}$ & $\begin{array}{r}9 \\
11 \\
11\end{array}$ & $\begin{array}{l}12 \\
15 \\
14\end{array}$ & $\begin{array}{l}(\mathbf{5 2}) \\
(\mathbf{6 3 )} \\
\mathbf{( 6 4 )}\end{array}$ \\
\hline $\begin{array}{l}2 \\
2 \\
3\end{array}$ & $\begin{array}{l}7 \\
7 \\
7\end{array}$ & $\begin{array}{l}11 \\
13 \\
14\end{array}$ & $\begin{array}{l}17 \\
16 \\
19\end{array}$ & $\begin{array}{l}18 \\
20 \\
23\end{array}$ & $\begin{array}{r}(92) \\
(96) \\
(109)\end{array}$ \\
\hline $\begin{array}{r}8 \\
8 \\
13\end{array}$ & $\begin{array}{l}17 \\
17 \\
17\end{array}$ & $\begin{array}{l}22 \\
27 \\
\mathbf{3 3}\end{array}$ & $\begin{array}{l}25 \\
33 \\
36\end{array}$ & $\begin{array}{l}27 \\
36 \\
39\end{array}$ & $\begin{array}{l}(171) \\
(206) \\
(237)\end{array}$ \\
\hline
\end{tabular}

The method of recording such observations is next considered.

The plotting of a graph is probably the best way of recording multiple results, but is time-consuming, and while it is convenient to compare a few observations of the same case, it is almost impossible to compare large numbers of different cases.

It is a great convenience if the S.R. can be expressed in a single number, provided that the number adequately reflects the variations in the S.R. at all readings. The recordings of the S.R. as a velocity expressed in $\mathrm{mm}$. per minute is not always easy to determine, as the curve rarely shows a constant fall over any appreciable period of time. It also requires constant attention during the whole period of observation. Any number which is to represent effectively the S.R. must incorporate a relationship between the variables space (distance fall) and time. A graph reveals this two-dimensional relationship very well.

The figures in the brackets in Tables I. and II. under the heading "Index" are an attempt to incorporate in a single number the variations revealed at every observation of the sedimentation. The relationship, as mentioned above, is a two-dimensional one, and the index is the ratio of the area above the graph to the area of the rectangle formed by the ordinate (space) and abcissa (time), and expressed as the percentage, multiplied by 10 , to obviate the use of the decimal point.

To simplify the calculation it is assumed that the fall between each reading is a straight line. This, of course, is not strictly correct, but as the curve is convex at one end and concave at the other they cancel out, and for all practical purposes the assumption is valid. The mathematical basis of the method is given below.

The area of ABZ, the portion of the rectangle ABCD above 
the graph, is easily determined by adding together the area of the triangle $A Y_{1} Z_{1}$ and the trapeziums $Y_{1} Y_{2} Z_{2} Z_{1}$, etc. This area, expressed as a percentage of the rectangle $A B C D$, is multi-

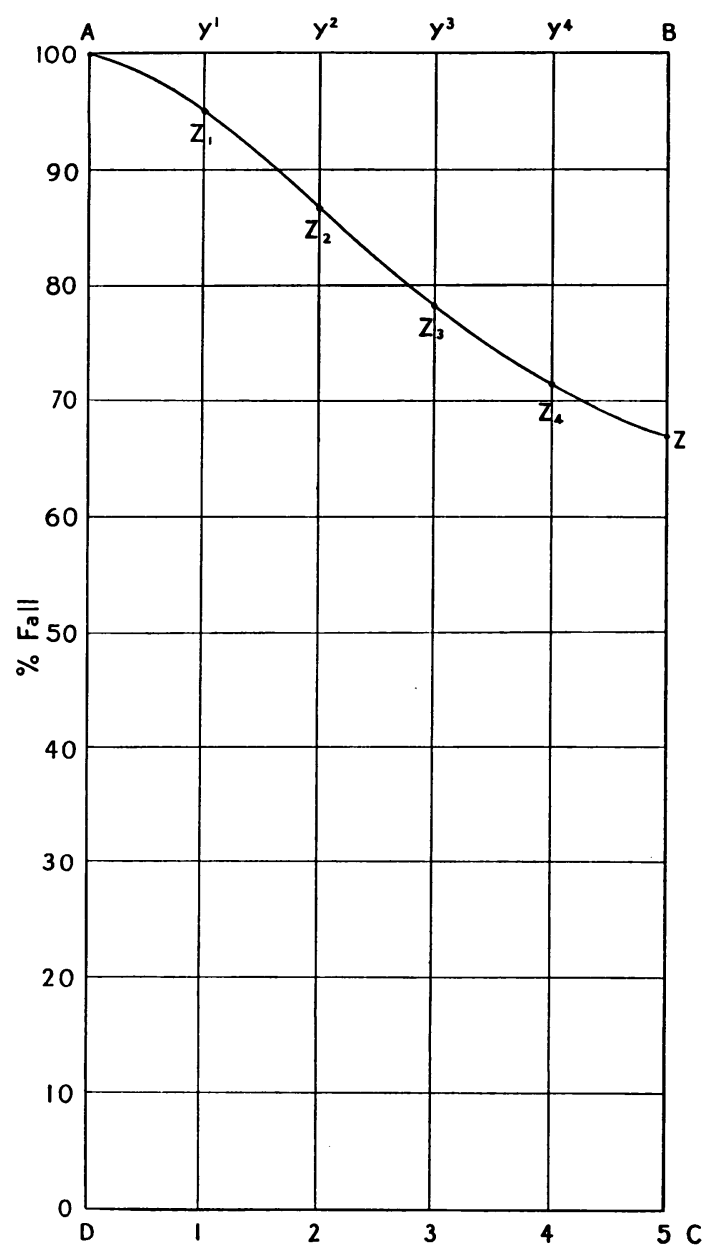

plied by 10 to obviate the decimal place. The calculation is made as follows:

Scade in Centimetres and Miutumetres.

The area of triangle $A Y_{1} Z_{1}$

$$
\begin{aligned}
& =\frac{1}{2} \times A Y_{1} \times Y_{1} Z_{1} \\
& =\frac{1}{2} \times 10 \times \text { fall at end of lst hour } \\
& =5 \times \text { fall at end of lst hour. }
\end{aligned}
$$


The area of trapezium $Y_{1} Y_{2} Z_{2} Z_{1}$

$$
\begin{aligned}
& =\frac{1}{2} Y_{1} Y_{2}\left(Y_{1} Z_{1}+Y_{2} Z_{2}\right) \\
& =\frac{1}{2} \times 10\left(Y_{1} Z_{1}+Y_{2} Z_{2}\right) \\
& =5 \times(\text { fall at end of } 1 \text { st hour +fall at 2nd hour }) .
\end{aligned}
$$

The area of trapezium $\mathrm{Y}_{2} \mathrm{Y}_{3} \mathrm{Z}_{3} \mathrm{Z}_{2}$

$$
=5 \times \text { sum of fall at } 2 \text { nd and } 3 \text { rd hour, and so on. }
$$

Total area of the portion above sedimentation graph is then: $5 \times$ [fall at 1st hour $+($ fall at 1 st +2 nd $) \ldots$ (fall at 4 th +5 th $)]$ expressed as a percentage of the area of the rectangle $A B C D$, which is $50 \times 100=5,000$ sq. mm.

$$
=\frac{100 \times 5 \times[\text { fall at 1st hour }+(\text { fall at lst }+2 \text { nd })+\ldots(\text { fall } 4 \text { th }+5 \text { th })]}{5000},
$$

and, as stated, the figure is expressed as per cent. $\times 10$; therefore the calculation is:

$$
\begin{gathered}
\frac{100 \times 10 \times 5 \times[\text { fall at } 1 \text { st }+(\text { fall at } 1 \text { st }+2 n d)], \text { etc. }}{5000} \\
=\frac{5000 \times \frac{[\text { fall at } 1 \text { st }+(\text { fall at lst }+2 \text { nd })], \text { etc. }}{5000}}{}
\end{gathered}
$$

\begin{tabular}{|c|c|c|c|c|c|c|c|}
\hline Time. & & & & & & & \\
\hline 1 hour & . & . & 1 & Put down & $\cdot$ & $\ldots$ & 1 \\
\hline 2 hours & . & . & 3 & Add lst and 2nd & & $\ldots$ & 4 \\
\hline 3 hours & . & .. & 4 & Add 2nd and 3rd & 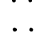 & $\ldots$ & 7 \\
\hline 4 hours & $\ldots$ & . & 6 & Add 3rd and 4th & & $\ldots$ & 10 \\
\hline 5 hours & . & . & 8 & Add 4 th and 5th & . & . & 14 \\
\hline
\end{tabular}

The 5,000 cancel, and we are left with

$=$ fall at 1st hour $+($ fall at 1 st +2 nd $)+($ fall at 2 nd +3 rd $)$

$+($ fall at 3 rd +4 th $)+($ fall at 4 th +5 th $)$.

The actual calculation, which appears so complicated, actually reduced to a very simple addition sum, as the following examples show:

This index 36 is the percentage $(\times 10)$ which the area $A B Z$ is of the rectangle $A B C D$.

\section{Index $36=3 \cdot 6$ per cent.}

This example demonstrates the method. It will be seen, however, that each reading, except the fifth hour, occurs twice in the calculation. It can be further simplified by performing the calculation in the following ways: 


\begin{tabular}{|c|c|c|c|c|c|c|c|}
\hline & \multicolumn{3}{|c|}{$\begin{array}{l}\text { Fall (mm. } \\
\text { per Cent.). }\end{array}$} & & & \\
\hline 1 hour & . & .. & 1 & Double & $\ldots$ & $\ldots$ & $\ldots=2$ \\
\hline 2 hours & .. & .. & 3 & Double & .. & $\ldots$ & $\ldots=6$ \\
\hline 3 hours & .. & .. & 4 & Double & .. & $\ldots$ & $\ldots=8$ \\
\hline 4 hours & .. & .. & 6 & Double & $\ldots$ & $\ldots$ & $\ldots=12$ \\
\hline 5 hours & .. & .. & 8 & Add & $\ldots$ & $\ldots$ & $\ldots=8$ \\
\hline
\end{tabular}

As the S.R. will have been measured in millimetres and the per cent. fall is the fall in millimetres divided by 2 , it is only necessary to add together the first, second, third and fourth readings in millimetres and then add half the fifth reading. Thus:

Time. $\quad$ Fall $(\mathrm{mm}$.).

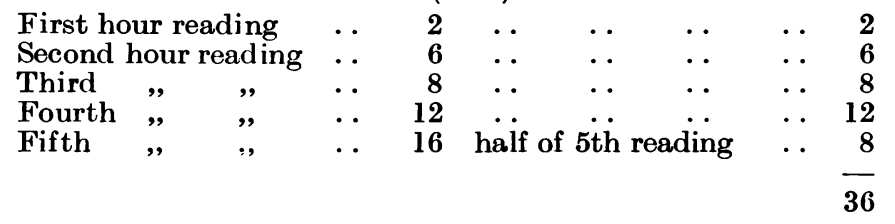

It will be seen that any variation in any reading will be reflected in the final index. The same mathematical treatment can be used to express in a single figure any series of multiple records which are at present best expressed by means of a graph.

These results are published by permissicn of Dr. Peter W. Edwards, Medical Superintendent; and to him and my colleague, Dr. Alan Lynn, my best thanks are due for their interest and suggestions.

\section{Conclusions and SummaRY}

1. The inadequacy of first or second, or both, hourly readings as a means of expressing the S.R. by the Westergren method is shown.

2. The disadvantages of the graphical representation are given.

3. An index is suggested and the mathematical basis of the index is indicated.

4. A suggestion made that the same method could be applied to any data which require graphical representation.

\section{REFERENCE}

Reports of Cheshire Joint Sanatorium, 1932-36. 